\title{
The effect on survival of continuing chemotherapy to near death
}

\author{
Akiko M Saito ${ }^{1}$, Mary Beth Landrum², Bridget A Neville ${ }^{3}$, John Z Ayanian ${ }^{2,4}$ and Craig C Earle ${ }^{5^{*}}$
}

\begin{abstract}
Background: Overuse of anti-cancer therapy is an important quality-of-care issue. An aggressive approach to treatment can have negative effects on quality of life and cost, but its effect on survival is not well-defined.

Methods: Using the Surveillance, Epidemiology, and End Results-Medicare database, we identified 7,879 Medicareenrolled patients aged 65 or older who died after having survived at least 3 months after diagnosis of advanced non-small cell lung cancer (NSCLC) between 1991 and 1999. We used Cox proportional hazards regression analysis, propensity scores, and instrumental variable analysis (IVA) to compare survival among patients who never received chemotherapy $(n=4,345)$, those who received standard chemotherapy but not within two weeks prior to death ( $n$ $=3,235)$, and those who were still receiving chemotherapy within 14 days of death $(n=299)$. Geographic variation in the application of chemotherapy was used as the instrument for IVA.
\end{abstract}

Results: Receipt of chemotherapy was associated with a 2-month improvement in overall survival. However, based on three different statistical approaches, no additional survival benefit was evident from continuing chemotherapy within 14 days of death. Moreover, patients receiving chemotherapy near the end of life were much less likely to enter hospice (81\% versus 51\% with no chemotherapy and 52\% with standard chemotherapy, $\mathrm{P}<0.001$ ), or were more likely to be admitted within only 3 days of death.

Conclusions: Continuing chemotherapy for advanced NSCLC until very near death is associated with a decreased likelihood of receiving hospice care but not prolonged survival. Oncologists should strive to discontinue chemotherapy as death approaches and encourage patients to enroll in hospice for better end-of-life palliative care.

\section{Background}

The paucity of information regarding cancer prognosis, treatment options, and the possible consequences of treatment make it difficult for terminally ill patients to make appropriate end-of-life treatment choices,[1-4] despite a growing awareness of the importance of high quality end-of-life care. We have previously shown that the aggressive use of chemotherapy in patients who are close to death has been increasing over time [5]. In fact, although an aggressive approach to treatment during the last week of life is linked to psychological and physical distress for advanced cancer patients,[6,7] little information is available about the clinical effects of such treatment [8]. A systematic review of the literature from

\footnotetext{
* Correspondence: craig.earle@ices.on.ca

${ }^{5}$ Health Services Research Program, Cancer Care Ontario and the Ontario Institute for Cancer Research, Toronto, ON, Canada

Full list of author information is available at the end of the article
}

the past two decades found that patients would choose chemotherapy near death for much smaller expected benefits in outcome than would health care providers, [4] indicating a skepticism on the part of physicians for this kind of care. Other studies have also shown that chemotherapy is used near death irrespective of the cancer's responsiveness to therapy $[9,10]$. Such treatment has been associated with potentially negative effects, including higher numbers of emergency room (ER) visits, hospitalizations, and admissions to the intensive care unit (ICU), and less hospice service [5,11]. These results beg the question of whether aggressive care leads to improved outcomes. To address this issue, we evaluated the effect of an aggressive approach to care, defined as continuation of chemotherapy within two weeks of death, on survival in a cohort of patients with metastatic non-small cell lung cancer.

\section{Biomed Central}

() 2011 Saito et al; licensee BioMed Central Ltd. This is an Open Access article distributed under the terms of the Creative Commons Attribution License (http://creativecommons.org/licenses/by/2.0), which permits unrestricted use, distribution, and reproduction in any medium, provided the original work is properly cited. 


\section{Methods \\ Definition of standard chemotherapy and aggressive- approach chemotherapy}

The receipt of chemotherapy for each patient was identified from billing claims [12]. For the purpose of this study, we defined 'no chemotherapy' patients as those who never received chemotherapy after their cancer diagnosis, 'standard chemotherapy' recipients as those who did receive chemotherapy for their cancer but not during the 14 days prior to death, and 'aggressive-approach chemotherapy' recipients as those who were still receiving chemotherapy within 14 days of death [13].

\section{Data sources and identification of the study cohort}

The study was approved by the Dana-Farber/Partners Cancer Care Institutional Review Board. The data for this study were extracted from the linked Surveillance, Epidemiology, and End Results (SEER)-Medicare database, compiled by the National Cancer Institute. Eleven tumor registries participated in the SEER program during the period of study. Approximately $97 \%$ of all the cancer cases that occur in the regions encompassed by the registries are captured,[14] covering a representative sample of approximately $14 \%$ of the United States population $[15,16]$. For each patient, SEER registries collect data on age, gender, race/ethnicity, cancer site, stage, histology, date of cancer diagnosis, and date of death. Data from the 2000 Census, such as the median and per capita income and wealth, have been merged with the registry data. Claims for inpatient and outpatient care, physician and laboratory services, and hospice care were retrieved from the Medicare database.

The potentially eligible study cohort included 15,391 patients who were 65 years or older, were diagnosed with metastatic non-small cell lung cancer, and died of their disease between 1991 and 1999. This cohort did not include patients who were enrolled in Medicare for end-stage renal failure or disability instead of older age, and those whose cancer diagnoses were detected from autopsy or death certificates. Patients who did not have continuous Medicare enrolment (Part A and Part B) or who were enrolled in a health maintenance organization (HMO) at any time in the year prior to death were also excluded. When estimating survival among three treatment groups in the potentially eligible study cohort, aggressive-approach chemotherapy recipients died very quickly compared to standard chemotherapy recipients $(\mathrm{P}<0.05$, data not shown), suggesting the possibility of high proportion of patients with rapid disease progression in the aggressive-approach chemotherapy group or a negative effect of such care. To eliminate the first case, we excluded patients who died within three months from their diagnosis $(n=7,512)$. This is consistent with the eligibility criteria for most clinical protocols that examine the effects of chemotherapy, which usually require patients to have at least a threemonth prognosis. Thus, a total of 7,879 patients were included in the final cohort. The excluded cohorts had a tendency not to receive any chemotherapy compared with the study cohort who survived at least 3 months (15\% versus (vs.) 45\%), while the proportion receiving chemotherapy near the end of life were the same between the two groups ( $4 \%$ vs. $4 \%$ ), suggesting the choice of aggressive-approach chemotherapy was not influenced by patients' prognoses. We also confirmed that the inclusion of the excluded cohort did not change the results in sensitivity analyses. These findings support the fact that the study cohort was valid and aggressiveapproach chemotherapy recipients were not just those with poor prognosis.

\section{Statistical analysis \\ 1) Definition and classification of explanatory variables}

Patients were categorized into three treatment groups: no chemotherapy, standard chemotherapy, or an aggressive approach to chemotherapy. Control variables included patient age at diagnosis, gender, race/ethnicity (non-Hispanic white, non-Hispanic black, Hispanic, or other), geographic region (Northeast, South, Midwest, or West), urban residence (densely-settled area with more than 2,500 residences-yes or no), whether they were treated at a teaching hospital at any time between cancer diagnosis and death (yes or no), and year of death. A Charlson comorbidity index $(0,1$, or 2 or more) was calculated by using the algorithm described elsewhere [17-19]. Socioeconomic quintiles were developed following the method described by Bach et al. [20]; Only eighty-six patients for whom no income data were available were grouped in the lowest quintile of socioeconomic status, and exclusion of their data did not change the results in sensitivity analyses. Based on billing information, patients were divided into three groups according to the length of hospice care (none, three or fewer days, or four or more days).

\section{2) Analytical approach}

Unadjusted comparison Descriptive statistical analyses to assess baseline sociodemographic and disease characteristics among patients in the three treatment groups were performed using Chi-square tests for categorical variables and Wilcoxon rank-sum tests for continuous variables, with the Kruskal-Wallis test used for overall comparisons. Overall survival (OS) was calculated using the Kaplan-Meier method,[21] and a log-rank test [22] was used for group comparisons.

Adjusted comparison-1: multiple Cox regression analysis We used a Cox proportional hazards regression model to compare relative risks and 95\% confidence intervals (95\% CIs) for mortality in the three treatment 
groups, unadjusted and adjusted for 9 key factors: patient age, gender, the Charlson comorbidity index, race/ethnicity, geographic region, urban residence, socioeconomic status, teaching hospital, and year of death. Any variables that were significantly associated with the receipt of chemotherapy in the univariate analyses were considered for inclusion in the model. Significant variables associated with survival were identified through stepwise selection, and interaction terms that revealed significant effect modification (i.e. the interaction term with treatment group was significant) were further investigated.

Adjusted comparison-2: propensity score analysis Propensity score (PS) approaches have been proposed as a less parametric alternative when there are large observed differences between treatment groups. The PS, introduced by Rosenbaum and Rubin in 1983,[23] is the conditional probability of assignment to a certain treatment procedure, given sociodemographic and disease characteristics. PS methods thus permit control for all observed confounding factors that might influence both choice of treatment and outcome using a single composite measure, without requiring specification of the relationships between the control variables and outcome, which differs from a Cox proportional hazards regression model.

We first calculated the propensity for receiving chemotherapy with a logistic regression model, which includes all the control variables. We examined the overlap in PS among patients who received chemotherapy and those who did not to ensure the suitability of comparing treatment outcome between the two groups. We then stratified the sample of patients into five propensity strata. Within each stratum, we estimated survival separately using a Cox proportional hazards regression model. A multivariable Cox regression adjustment using PS as a continuous variable was also performed.

The same process was repeated for patients who ever received chemotherapy: the propensity for undergoing an aggressive approach to chemotherapy was calculated, patients were divided into five propensity strata, and survival was estimated using both a Cox proportional hazards regression model within each stratum in which confounding factors were substantially reduced [23,24] and a multivariable Cox regression adjustment using PS as a continuous variable.

Adjusted comparison-3: instrumental variable analysis The two preceding statistical tools do not directly consider unobserved factors that may be unrelated to observed variables, but may nevertheless affect treatment choices and/or their outcomes. The instrumental variable analysis (IVA) method, first developed in the field of econometrics [25] and applied to the field of health care research since the mid-1990s,[12,26-29] permits the consideration of not only observed factors, but also unobserved factors that might influence outcomes.

The instrumental variable (IV) in an IVA should independently influence patients' or physicians' treatment choice, but should not be associated with outcomes. On the basis of findings from several published studies, $[30,31]$ we used treatment rates within Health Care Service Areas (HCSAs),[32] a classification of geographic areas based on observed referral patterns for tertiary care, and stratified by the availability of health care resources, as the IV. To confirm the assumption of this analysis, we included the IVs in a Cox proportional hazards regression model to determine that it would not predict survival independently. Also, we confirmed that sociodemographic and disease characteristics across IVs are more similar than when we compared those characteristics among the three treatment groups.

First, we calculated the numbers of elderly patients receiving chemotherapy for advanced lung cancer in each HCSA. HCSAs with five or fewer patients treated with or without chemotherapy were excluded. The remaining HCSAs were divided into quintiles based on the proportion of patients receiving chemotherapy. We then calculated the IV estimates for the "marginal patient population," which is defined as patients who would receive chemotherapy if they lived in a HCSA with a high chemotherapy utilization rate but not if they lived in a HCSA with low chemotherapy utilization rate [33]. A non-parametric two-stage least squares model was used to predict treatment in the first stage based on IV quintiles. These models also controlled for patient age, race/ethnicity, gender, socioeconomic status, Charlson comorbidity index, and the year of death. Among those who ever received chemotherapy, we took the same approach from the perspective of more and less aggressive-approach chemotherapy utilization and estimated the clinical effect of receiving chemotherapy within 14 days of death for the marginal patient population.

All tests were two-tailed, and P-values less than 0.05 were considered significant. All analyses were performed using SAS software, version 9.1 (SAS Institute, Cary, $\mathrm{NC}$ )

\section{Results}

\section{Patient characteristics}

Table 1 summarizes the characteristics of the study population. Of the 7,879 patients, 3,534 patients (44.9\%) had ever received chemotherapy, and 299 (8.5\%) of those patients were still receiving chemotherapy within 14 days of death.

Several factors differed between patients who received chemotherapy and those who did not. Recipients of 
Table 1 Characteristics of 7,879 patients with metastatic non-small cell lung cancer by receipt of chemotherapy

\begin{tabular}{|c|c|c|c|c|c|c|c|}
\hline \multicolumn{2}{|l|}{ Variables } & \multirow{2}{*}{$\begin{array}{c}\text { No } \\
\text { chemotherapy } \\
(n=4,345)\end{array}$} & \multirow{2}{*}{$\begin{array}{c}\text { Standard } \\
\text { chemotherapy } \\
(n=3,235)\end{array}$} & \multirow{2}{*}{$\begin{array}{c}\text { Aggressive } \\
\text {-approach } \\
\text { chemotherapy } \\
(n=299)\end{array}$} & \multicolumn{3}{|c|}{ P-value } \\
\hline & & & & & $\begin{array}{c}3 \\
\text { groups }\end{array}$ & $\begin{array}{l}\text { No chemo- } \\
\text { therapy vs. } \\
\text { Chemo- therapy* }\end{array}$ & $\begin{array}{c}\text { Standard chemotherapy vs. } \\
\text { Aggressive -approach } \\
\text { chemotherapy }\end{array}$ \\
\hline $\begin{array}{l}\text { Age at diagnosis, } \\
\text { years }\end{array}$ & $\begin{array}{l}\text { Median } \\
{[\text { [QR] }}\end{array}$ & 73.0 [69.0-78.0] & $71.0[68.0-74.0]$ & $70.0[67.0-74.0]$ & $<0.001$ & $<0.001$ & 0.36 \\
\hline \multirow[t]{2}{*}{ Gender, n (\%) } & Female & $1,938(44.6)$ & 1,291 (39.9) & $108(36.1)$ & $<0.001$ & $<0.001$ & 0.20 \\
\hline & Male & $2,407(55.4)$ & $1,944(60.1)$ & $191(63.9)$ & & & \\
\hline \multirow{3}{*}{$\begin{array}{l}\text { Charlson comorbidity } \\
\text { index, n (\%) }\end{array}$} & 0 & $3,123(71.9)$ & $2,401(74.2)$ & $226(75.6)$ & $<0.001$ & $<0.001$ & 0.06 \\
\hline & 1 & $773(17.8)$ & $576(17.8)$ & $60(20.1)$ & & & \\
\hline & $2 \leq$ & $449(10.3)$ & $258(8.0)$ & $13(4.4)$ & & & \\
\hline \multirow[t]{3}{*}{ Race/Ethnicity, n (\%) } & $\begin{array}{l}\text { non- } \\
\text { Hispanic } \\
\text { white }\end{array}$ & $3,551(81.7)$ & $2,711(83.8)$ & $254(85.0)$ & 0.01 & 0.01 & 0.22 \\
\hline & $\begin{array}{l}\text { non- } \\
\text { Hispanic } \\
\text { black }\end{array}$ & $425(9.8)$ & $248(7.7)$ & $21(7.0)$ & & & \\
\hline & $\begin{array}{l}\text { Hispanic } \\
\text { or other }\end{array}$ & $369(8.5)$ & $276(8.5)$ & $24(8.0)$ & & & \\
\hline \multirow{4}{*}{$\begin{array}{l}\text { Region of tumor } \\
\text { registries, n (\%) }\end{array}$} & Northeast & $672(15.5)$ & $555(17.2)$ & $51(17.1)$ & $<0.01$ & $<0.01$ & 0.06 \\
\hline & South & $228(5.3)$ & $194(6.0)$ & $28(9.4)$ & & & \\
\hline & Midwest & $1,426(32.8)$ & $1,101(34.0)$ & $86(28.8)$ & & & \\
\hline & West & $2019(46.5)$ & $1385(42.8)$ & $134(44.8)$ & & & \\
\hline \multirow{2}{*}{$\begin{array}{l}\text { Urban residence, } \mathrm{n} \\
\text { (\%) }\end{array}$} & Yes & $3,928(90.4)$ & 2,973 (91.9) & $284(95.0)$ & $<0.01$ & $<0.01$ & 0.06 \\
\hline & No & 417 (9.6) & $262(8.1)$ & $15(5.0)$ & & & \\
\hline \multirow[t]{5}{*}{$\begin{array}{l}\text { Socioeconomic status, } \\
\text { n (\%) }\end{array}$} & $\begin{array}{l}\text { Highest } \\
\text { quintile }\end{array}$ & $763(17.6)$ & $682(21.1)$ & $71(23.8)$ & $<0.001$ & $<0.001$ & 0.85 \\
\hline & $\begin{array}{l}\text { Fourth } \\
\text { quintile }\end{array}$ & $793(18.3)$ & $673(20.8)$ & $63(21.1)$ & & & \\
\hline & $\begin{array}{l}\text { Third } \\
\text { quintile }\end{array}$ & $866(19.9)$ & $688(21.3)$ & $59(19.7)$ & & & \\
\hline & $\begin{array}{l}\text { Second } \\
\text { quintile }\end{array}$ & $849(19.5)$ & $635(19.6)$ & $56(18.7)$ & & & \\
\hline & $\begin{array}{l}\text { Lowest } \\
\text { quintile }\end{array}$ & $1,074(24.7)$ & $557(17.2)$ & $50(16.7)$ & & & \\
\hline Median income & $\begin{array}{l}\text { Median } \\
\text { [IQR] }\end{array}$ & 38,154 [29-152] & 41,205 [32-757] & $43,564[32-179]$ & $<0.001$ & $<0.001$ & 0.28 \\
\hline \multirow{2}{*}{$\begin{array}{l}\text { Teaching hospital, n } \\
(\%)\end{array}$} & Yes & $2,110(48.6)$ & $1,868(57.7)$ & $163(54.5)$ & $<0.001$ & $<0.001$ & 0.28 \\
\hline & No & 2,235 (51.4) & $1,367(42.3)$ & $136(45.5)$ & & & \\
\hline \multirow[t]{9}{*}{ Year of death, n (\%) } & 1991 & $365(8.4)$ & $206(6.4)$ & $18(6.0)$ & $<0.001$ & $<0.001$ & 0.02 \\
\hline & 1992 & $576(13.3)$ & $299(9.2)$ & $22(7.4)$ & & & \\
\hline & 1993 & $567(13.1)$ & $340(10.5)$ & $15(5.0)$ & & & \\
\hline & 1994 & $581(13.4)$ & $339(10.5)$ & $33(11.0)$ & & & \\
\hline & 1995 & 518 (11.9) & $372(11.5)$ & $33(11.0)$ & & & \\
\hline & 1996 & $490(11.3)$ & $424(13.1)$ & $32(10.7)$ & & & \\
\hline & 1997 & $442(10.2)$ & $413(12.8)$ & $46(15.4)$ & & & \\
\hline & 1998 & $421(9.7)$ & $421(13.0)$ & $52(17.4)$ & & & \\
\hline & 1999 & $385(8.9)$ & $421(13.0)$ & $48(16.1)$ & & & \\
\hline \multirow{2}{*}{$\begin{array}{l}\text { Death in the hospital, } \\
\text { n (\%) }\end{array}$} & Yes & $774(17.8)$ & $812(25.1)$ & $152(50.8)$ & $<0.001$ & $<0.001$ & $<0.001$ \\
\hline & No & 3,571 (82.2) & 2,423 (74.9) & 147 (49.2) & & & \\
\hline
\end{tabular}


Table 1 Characteristics of 7,879 patients with metastatic non-small cell lung cancer by receipt of chemotherapy (Continued)

\begin{tabular}{|c|c|c|c|c|c|c|c|}
\hline \multirow{2}{*}{$\begin{array}{l}\text { ICU admission within } \\
1 \text { month of death, } n \\
\text { (\%) }\end{array}$} & Yes & $187(4.3)$ & 213 (6.6) & $37(12.4)$ & $<0.001$ & $<0.001$ & $<0.001$ \\
\hline & No & $4,158(95.7)$ & $3,022(93.4)$ & $262(87.6)$ & & & \\
\hline \multirow{2}{*}{$\begin{array}{l}\text { More than } 1 \text { ER visit } \\
\text { within } 1 \text { month of } \\
\text { death, } \mathrm{n}(\%)\end{array}$} & Yes & $870(20.0)$ & $857(26.5)$ & $104(34.8)$ & $<0.001$ & $<0.001$ & $<0.01$ \\
\hline & No & $3,475(80.0)$ & $2,378(73.5)$ & $195(65.2)$ & & & \\
\hline \multirow{3}{*}{$\begin{array}{l}\text { Hospice admission, } \mathrm{n} \\
(\%)\end{array}$} & None & $2,208(50.8)$ & $1,668(51.6)$ & 241 (80.6) & $<0.001$ & $<0.001$ & $<0.001$ \\
\hline & $\begin{array}{c}\text { Three or } \\
\text { fewer } \\
\text { days }\end{array}$ & 156 (3.6) & $198(6.1)$ & $25(8.4)$ & & & \\
\hline & $\begin{array}{l}\text { Four or } \\
\text { more } \\
\text { days }\end{array}$ & 1,981 (45.6) & $1,369(42.3)$ & $33(11.0)$ & & & \\
\hline
\end{tabular}

Abbreviation: vs., versus; IQR, interquartile range; ICU, intensive care unit; ER, emergency room.

*Chemotherapy includes standard chemotherapy or aggressive-approach chemotherapy

chemotherapy, whether standard or aggressive-approach chemotherapy, were younger, more likely to be male, and less likely to have comorbidity compared with nonrecipients. The chemotherapy group had more non-Hispanic white patients and those who were more likely to reside in the Northeast or South, in urban areas, be admitted to teaching hospitals, have higher socioeconomic status, and to have died in more recent years compared with the no chemotherapy group. Among patients who ever received chemotherapy, recipients of chemotherapy near death had less comorbidity and tended to have died in more recent years, were more likely to reside in the South, were less likely to reside in the Midwest, and more often resided in urban areas compared to standard chemotherapy recipients.

\section{Unadjusted outcomes}

Deaths in the hospital, ER visits and ICU admissions were more common in patients who received standard chemotherapy compared to patients who did not receive chemotherapy, and each of these outcomes occurred even more frequently in recipients of chemotherapy near death (Table 1). Over $40 \%$ of patients in the group without chemotherapy or those in the standard chemotherapy group had hospice stays of four or more days, compared with only $11 \%$ of those in the aggressive-approach chemotherapy group; in fact, over $80 \%$ of those receiving chemotherapy near death received no hospice care (Table 1). The unadjusted survival rates among the three groups by receipt of chemotherapy are shown in Figure 1. The median survival of patients who received no chemotherapy, standard chemotherapy, and aggressive-approach chemotherapy were 6 months, 8 months, and 8 months, respectively. Survival of these three groups at 1 year was $18.6 \%$ for the group with no chemotherapy, $27.2 \%$ for the standard chemotherapy group, and $28.6 \%$ for the aggressive-approach chemotherapy group, respectively ( 3 groups, $\mathrm{P}<0.001$; no chemotherapy vs. any chemotherapy, $\mathrm{P}<0.001$; standard chemotherapy vs. aggressive-approach chemotherapy, $\mathrm{P}$ $=0.83$ ).

\section{Adjusted outcomes}

\section{1) Results from Cox model}

In the Cox regression analysis, adjusted hazard ratios (HR) of patients with standard chemotherapy or chemotherapy near death were significantly lower compared to patients who received no chemotherapy, overlapping confidence intervals between recipients of standard and aggressive-approach chemotherapy approaches (standard

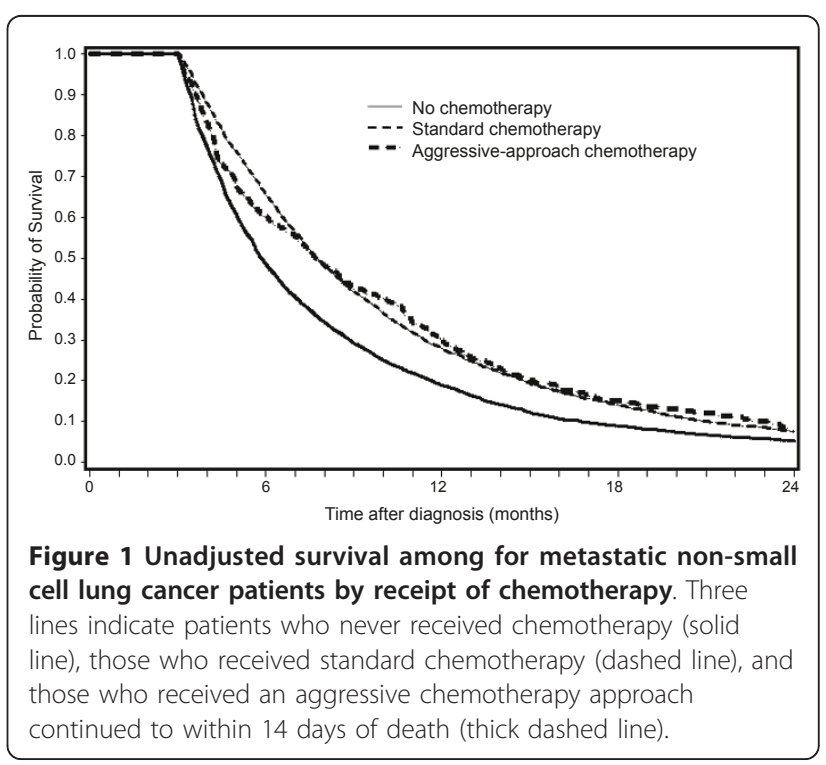


chemotherapy, $\mathrm{HR}=0.80,95 \% \mathrm{CI} 0.76,0.83, \mathrm{P}<0.001$; aggressive-approach chemotherapy, $\mathrm{HR}=0.82,95 \% \mathrm{CI}$ $0.72,0.92, \mathrm{P}<0.001$, Table 2). When making standard chemotherapy the reference group (data not shown), no chemotherapy was associated with worse survival $(\mathrm{HR}=$ $1.26,95 \%$ CI $1.20,1.32, \mathrm{P}<0.001)$ and chemotherapy near the end of life did not have any impact on survival compared to standard chemotherapy $(\mathrm{HR}=1.03,95 \% \mathrm{CI}$ $0.91,1.16, \mathrm{P}=0.66$ ). Older age at diagnosis, male gender, worse comorbidity index, and residence in the West were associated with worse survival. Race/ethnicity, urban residence, socioeconomic status, and treatment in teaching hospitals were not related to survival. Significantly improved survival was evident in 1998 and 1999 relative to 1991 (Table 2).

\section{2) Results from propensity score analyses}

Care in a teaching hospital was more likely to be provided to chemotherapy recipients compared to non-recipients, whereas among patients who ever received chemotherapy, those in teaching hospitals were less likely to receive chemotherapy near death. Prognostic factors were well balanced across the propensity strata. There was considerable overlap in the PSs of chemotherapy recipients compared to non-recipients. Mean PS to receive chemotherapy was 0.50 (95\%CI $0.23,0.77$ ) in the chemotherapy group and was 0.41 in the group with no chemotherapy ( $95 \% \mathrm{CI} 0.12,0.70)$. Standard chemotherapy recipients had a mean PS to receive aggressive-approach chemotherapy of 0.08 (95\%CI 0.02, 0.15), while those with aggressive-approach chemotherapy had a mean PS of 0.10 (95\%CI 0.03, 0.16).

The Cox regression model using the PS is shown in Table 3. The Cox regression adjustment using the PS as a continuous variable showed that the HR for chemotherapy recipients was 0.76 (95\%CI $0.71,0.82, \mathrm{P}<$ 0.001 ), and those stratified by the PS quintiles found that it ranged from 0.73 to 0.85 across propensity strata (all $\mathrm{P}<0.01$ ). Of those who received any chemotherapy (Table 4), the HR for aggressive-approach chemotherapy recipients was $1.21(95 \% \mathrm{CI} 1.00,1.48, \mathrm{P}=0.05)$ from the Cox regression adjustment using the PS as a continuous variable. There appeared to be a trend of

Table 2 Factors significantly associated with survival in multiple Cox regression analysis

\begin{tabular}{|c|c|c|c|c|}
\hline \multicolumn{2}{|c|}{ Variables } & \multirow{2}{*}{$\begin{array}{l}\mathbf{H R} \\
1.00\end{array}$} & \multirow{2}{*}{$\begin{array}{c}(95 \% \mathrm{Cl}) \\
-\end{array}$} & \multirow{2}{*}{$\frac{\text { P-value }}{-}$} \\
\hline Receipt of chemotherapy & No chemotherapy & & & \\
\hline & Standard chemotherapy & 0.80 & $(0.76,0.83)$ & $<0.001$ \\
\hline & Aggressive-approach chemotherapy & 0.82 & $(0.72,0.92)$ & $<0.001$ \\
\hline \multirow[t]{2}{*}{ Age at diagnosis } & 65 & 1.00 & - & - \\
\hline & Each increasing year & 1.01 & $(1.00,1.01)$ & $<0.001$ \\
\hline \multirow[t]{2}{*}{ Gender } & Female & 1.00 & - & - \\
\hline & Male & 1.09 & $(1.05,1.14)$ & $<0.001$ \\
\hline \multirow[t]{3}{*}{ Charlson comorbidity index } & 0 & 1.00 & - & - \\
\hline & 1 & 1.16 & $(1.09,1.23)$ & $<0.001$ \\
\hline & $2 \leq$ & 1.28 & $(1.18,1.38)$ & $<0.001$ \\
\hline \multirow[t]{4}{*}{ Region of tumor registries } & Northeast & 1.00 & - & - \\
\hline & South & - & - & n.s. \\
\hline & Midwest & - & - & n.s. \\
\hline & West & 1.08 & $(1.03,1.13)$ & $<0.001$ \\
\hline \multirow[t]{2}{*}{ Socioeconomic status } & Lowest quintile & 1.00 & - & - \\
\hline & Each increasing quintile & - & - & n.s. \\
\hline \multirow[t]{2}{*}{ Teaching hospital } & No & 1.00 & - & - \\
\hline & Yes & - & - & n.s. \\
\hline \multirow[t]{9}{*}{ Year of death } & 1991 & 1.00 & - & - \\
\hline & 1992 & 1.11 & $(1.04,1.19)$ & $<0.01$ \\
\hline & 1993 & - & - & n.s. \\
\hline & 1994 & - & - & n.s. \\
\hline & 1995 & - & - & n.s. \\
\hline & 1996 & - & - & n.s. \\
\hline & 1997 & - & - & n.s. \\
\hline & 1998 & 0.91 & $(0.84,0.97)$ & $<0.01$ \\
\hline & 1999 & 0.89 & $(0.82,0.96)$ & $<0.01$ \\
\hline
\end{tabular}

Abbreviation: $\mathrm{HR}$, hazard ratio; $\mathrm{Cl}$, confidence interval; n.s., not significant.

NOTE: Stepwise selection was used. Race/ethnicity, and living in urban region were not found to be significant predictors of survival in univariate analysis (Pvalue $>0.20$ ). 
Table 3 Propensity score analysis results 1: Survival impact across quintiles based on the propensity to receive chemotherapy among patients with metastatic non-small cell lung cancer, who survived at least 3 months after their cancer diagnosis $(\mathbf{n}=\mathbf{7 , 8 7 9})$

\begin{tabular}{|c|c|c|c|c|}
\hline Analysis & Variables & HR & $(95 \% \mathrm{Cl})$ & P-value \\
\hline \multicolumn{5}{|l|}{ Stratified analysis } \\
\hline \multirow[t]{2}{*}{ Lowest quintile of PS* } & No chemotherapy & 1.00 & - & - \\
\hline & Chemotherapy & 0.82 & $(0.73,0.93)$ & $<0.01$ \\
\hline \multirow[t]{2}{*}{ Second quintile of PS } & No chemotherapy & 1.00 & - & - \\
\hline & Chemotherapy & 0.77 & $(0.69,0.85)$ & $<0.001$ \\
\hline \multirow[t]{2}{*}{ Third quintile of PS } & No chemotherapy & 1.00 & - & - \\
\hline & Chemotherapy & 0.81 & $(0.74,0.90)$ & $<0.001$ \\
\hline \multirow[t]{2}{*}{ Fourth quintile of PS } & No chemotherapy & 1.00 & - & - \\
\hline & Chemotherapy & 0.85 & $(0.77,0.93)$ & $<0.01$ \\
\hline \multirow[t]{2}{*}{ Highest quintile of $\mathrm{PS}^{\dagger}$} & No chemotherapy & 1.00 & - & - \\
\hline & Chemotherapy & 0.73 & $(0.66,0.81)$ & $<0.001$ \\
\hline \multirow[t]{2}{*}{ Multiple Cox regression adjustment using the PS } & No chemotherapy & 1.00 & - & - \\
\hline & Chemotherapy & 0.76 & $(0.71,0.82)$ & $<0.001$ \\
\hline
\end{tabular}

Abbreviation: $\mathrm{HR}$, hazard ratio; $\mathrm{Cl}$, confidence interval; $\mathrm{PS}$, propensity score.

* Patients are least likely to receive "chemotherapy."

† Patients are most likely to receive "chemotherapy."

decreasing hazards with a greater propensity to receive chemotherapy near death, ranging from 1.32 to 0.85 , and the interaction between receipt of an aggressive approach to chemotherapy and propensity quintiles was marginally significant $(\mathrm{P}=0.07)$.

3) Results from instrumental variable analysis

We report selected baseline characteristics of patients according to geographic quintiles of chemotherapy utilization in Table 5. Thirty-one percent of the 1,492 patients in the lowest quintile received chemotherapy, and $52 \%$ of the 2,139 patients in the highest quintile received chemotherapy. Patients were similar in most observed characteristics including age, gender, race/ethnicity, and socioeconomic status. In addition, the Cox proportional hazards regression model showed that the IV was not an independent predictor of survival supporting its use as an instrumental variable. Using quintile of chemotherapy utilization as an instrumental variable, we did not observe an association between use of chemotherapy and survival for marginal patients at 1 year (6.7 percentage points; $95 \% \mathrm{CI}-6.6$, $19.9 \% ; \mathrm{P}=0.32$ ) or at 2 years (1.7 percentage points; $95 \%$ CI -5.9, 9.3\%; P = 0.66).

Similarly, in model 2, we compared survival across quintiles based on the rate of chemotherapy utilization

Table 4 Propensity score analysis results 2: Survival impact across quintiles based on the propensity to receive aggressive-approach chemotherapy within 14 days of death among chemotherapy recipients with metastatic nonsmall cell lung cancer, who survived at least 3 months after their cancer diagnosis $(n=3,534)$

\begin{tabular}{|c|c|c|c|c|}
\hline Analysis & Variables & HR & $(95 \% \mathrm{Cl})$ & P-value \\
\hline \multicolumn{5}{|l|}{ Stratified analysis } \\
\hline \multirow[t]{2}{*}{ Lowest quintile of PS* } & Standard chemotherapy & 1.00 & - & - \\
\hline & Aggressive-approach chemotherapy & 1.32 & $(0.90,1.92)$ & 0.15 \\
\hline \multirow[t]{2}{*}{ Second quintile of PS } & Standard chemotherapy & 1.00 & - & - \\
\hline & Aggressive-approach chemotherapy & 1.30 & $(0.98,1.72)$ & 0.07 \\
\hline \multirow[t]{2}{*}{ Third quintile of PS } & Standard chemotherapy & 1.00 & - & - \\
\hline & Aggressive-approach chemotherapy & 1.22 & $(0.81,1.84)$ & 0.35 \\
\hline \multirow[t]{2}{*}{ Fourth quintile of PS } & Standard chemotherapy & 1.00 & - & - \\
\hline & Aggressive-approach chemotherapy & 1.21 & $(0.94,1.56)$ & 0.14 \\
\hline \multirow[t]{2}{*}{ Highest quintile of $\mathrm{PS}^{\dagger}$} & Standard chemotherapy & 1.00 & - & - \\
\hline & Aggressive-approach chemotherapy & 0.85 & $(0.68,1.07)$ & 0.16 \\
\hline \multirow[t]{2}{*}{ Multiple Cox regression adjustment using the PS } & Standard chemotherapy & 1.00 & - & - \\
\hline & Aggressive-approach chemotherapy & 1.21 & $(1.00,1.48)$ & 0.05 \\
\hline
\end{tabular}

Abbreviation: $\mathrm{HR}$, hazard ratio; $\mathrm{Cl}$, confidence interval; $\mathrm{PS}$, propensity score.

* Patients are least likely to receive "aggressive-approach chemotherapy within 14 days of death."

† Patients are most likely to receive "aggressive-approach chemotherapy within 14 days of death." 
Table 5 Instrumental variable analysis results

\begin{tabular}{|c|c|c|c|c|c|c|c|c|c|}
\hline Model & $\begin{array}{c}\text { Patient } \\
\text { population }\end{array}$ & $\begin{array}{l}\text { Variable used for } \\
\text { classification }\end{array}$ & Variables & $\begin{array}{l}\text { Lowest } \\
\text { quintile }\end{array}$ & $\begin{array}{l}\text { Second } \\
\text { quintile }\end{array}$ & $\begin{array}{l}\text { Third } \\
\text { quintile }\end{array}$ & $\begin{array}{l}\text { Fourth } \\
\text { quintile }\end{array}$ & $\begin{array}{l}\text { Highest } \\
\text { quintile }\end{array}$ & $\begin{array}{l}\text { Instrumental } \\
\text { variable } \\
\text { estimate }\end{array}$ \\
\hline \multirow[t]{11}{*}{1} & $\begin{array}{l}\text { All patients } \\
(\mathrm{n}=7,879)\end{array}$ & $\begin{array}{l}\text { Prevalence of } \\
\text { "chemotherapy" }\end{array}$ & Number of patients* & 1,492 & 1,388 & 1,439 & 1,255 & 2,139 & \\
\hline & & & $\begin{array}{c}\text { Chemotherapy recipients, } \\
\%^{\dagger}\end{array}$ & 30.8 & 43.4 & 47.5 & 49.8 & 52.3 & \\
\hline & & & $\begin{array}{c}\text { Aggressive-approach } \\
\text { chemotherapy recipients, } \\
\%^{\dagger}\end{array}$ & 2.2 & 3.2 & 4.2 & 5.1 & 4.4 & \\
\hline & & & Age at diagnosis, years & 73.0 & 73.3 & 72.8 & 73.3 & 72.8 & \\
\hline & & & Female, \% & 42.2 & 41.7 & 42.6 & 48.3 & 39.8 & \\
\hline & & & non-Hispanic white, \% & 83.7 & 85.4 & 88.1 & 71.9 & 82.8 & \\
\hline & & & $\begin{array}{l}\text { Socioeconomic status, } \\
\text { mean quintile }\end{array}$ & 2.9 & 2.8 & 3.0 & 3.1 & 3.0 & \\
\hline & & & Without comorbidity, \% & 78.2 & 73.7 & 74.5 & 69.8 & 69.1 & \\
\hline & & & $\begin{array}{c}\text { Survival at } 1 \text { year after } \\
\text { diagnosis, } \%^{\mp}\end{array}$ & $\begin{array}{c}21.7 \pm \\
1.1\end{array}$ & $\begin{array}{c}23.5 \pm \\
1.1\end{array}$ & $\begin{array}{c}22.2 \pm \\
1.1\end{array}$ & $\begin{array}{c}21.7 \pm \\
1.2\end{array}$ & $\begin{array}{c}23.7 \pm \\
0.9\end{array}$ & $\begin{array}{l}6.7 \%(95 \% \mathrm{Cl}: \\
-6.6,19.9)\end{array}$ \\
\hline & & & $\begin{array}{l}\text { Survival at } 2 \text { years after } \\
\text { diagnosis, } \%^{\ddagger}\end{array}$ & $\begin{array}{c}5.6 \pm \\
0.6\end{array}$ & $6.7 \pm 0.7$ & $\begin{array}{c}6.1 \pm \\
0.6\end{array}$ & $\begin{array}{c}4.8 \pm \\
0.6\end{array}$ & $6.8 \pm 0.5$ & $\begin{array}{c}1.7 \%(95 \% \mathrm{Cl}: \\
-5.9,9.3)\end{array}$ \\
\hline & & & Hazard Ratio $(95 \% \mathrm{Cl})^{\S}$ & 1.0 & $\begin{array}{c}0.94 \\
(0.87 \\
1.01)\end{array}$ & $\begin{array}{c}0.96 \\
(0.89 \\
1.03)\end{array}$ & $\begin{array}{r}1.04 \\
(0.96 \\
1.12)\end{array}$ & $\begin{array}{l}0.93 \\
(0.87 \\
0.99)\end{array}$ & \\
\hline \multirow[t]{11}{*}{2} & $\begin{array}{l}\text { Chemotherapy } \\
\text { recipients } \\
(\mathrm{n}=3,534)\end{array}$ & $\begin{array}{l}\text { Prevalence of "aggressive- } \\
\text { approach chemotherapy" }\end{array}$ & Number of patients" & 453 & 136 & 990 & 619 & 614 & \\
\hline & & & $\begin{array}{c}\text { Chemotherapy recipients, } \\
\%\end{array}$ & 100.0 & 100.0 & 100.0 & 100.0 & 100.0 & \\
\hline & & & $\begin{array}{c}\text { Aggressive-approach } \\
\text { chemotherapy recipients, } \\
\%^{\dagger}\end{array}$ & 4.6 & 6.6 & 7.7 & 10.3 & 12.1 & \\
\hline & & & Age at diagnosis, years & 71.7 & 71.7 & 71.1 & 71.7 & 71.9 & \\
\hline & & & Female, \% & 43.7 & 44.1 & 38.6 & 41.7 & 43.3 & \\
\hline & & & non-Hispanic white, \% & 89.0 & 83.8 & 84.6 & 86.0 & 74.8 & \\
\hline & & & $\begin{array}{l}\text { Socioeconomic status, } \\
\text { mean quintile }\end{array}$ & 3.0 & 3.3 & 3.2 & 3.2 & 3.2 & \\
\hline & & & Without comorbidity, \% & 73.5 & 78.7 & 70.6 & 79.2 & 68.2 & \\
\hline & & & $\begin{array}{c}\text { Survival at } 1 \text { year after } \\
\text { diagnosis, } \%^{\mp}\end{array}$ & $\begin{array}{c}30.5 \pm \\
2.2\end{array}$ & $\begin{array}{l}29.4 \pm \\
3.9\end{array}$ & $\begin{array}{l}26.0 \pm \\
1.4\end{array}$ & $\begin{array}{l}26.3 \pm \\
1.8\end{array}$ & $\begin{array}{c}27.9 \pm \\
1.8\end{array}$ & $\begin{array}{l}-53.5 \%(95 \% \mathrm{Cl}: \\
-124.1,17.2)\end{array}$ \\
\hline & & & $\begin{array}{c}\text { Survival at } 2 \text { years after } \\
\text { diagnosis, } \%^{\ddagger}\end{array}$ & $\begin{array}{c}8.4 \pm \\
1.3\end{array}$ & $8.1 \pm 2.3$ & $\begin{array}{c}7.4 \pm \\
0.8\end{array}$ & $\begin{array}{c}6.5 \pm \\
1.0\end{array}$ & $6.2 \pm 1.0$ & $\begin{array}{c}-35.1 \%(95 \% \mathrm{Cl}: \\
-76.9,6.6)\end{array}$ \\
\hline & & & Hazard Ratio $(95 \% \mathrm{Cl})^{\S}$ & 1.0 & $\begin{array}{l}1.05 \\
(0.87 \\
1.28)\end{array}$ & $\begin{array}{l}1.07 \\
(0.96, \\
1.20)\end{array}$ & $\begin{array}{l}1.11 \\
(0.98 \\
1.25)\end{array}$ & $\begin{array}{l}1.11 \\
(0.99 \\
1.26)\end{array}$ & \\
\hline
\end{tabular}

Abbreviation: $\mathrm{Cl}$, confidence interval; $\mathrm{SE}$, standard error.

* A total of 166 patients who reside in the Health Care Service Areas, where there were five or fewer patients treated with or without chemotherapy, were excluded.

$+\mathrm{P}<0.001$

\# Unadjusted survival derived from Kaplan-Meier method

$\S$ Adjusted hazard ratios and 95\% confidence intervals derived from Cox proportional hazards regression model. Patient age, gender, race/ethnicity, socioeconomic status quintiles, Charlson comorbidity index, and year of death were included in the model.

|| A total of 722 patients who reside in the Health Care Service Areas, where there were five or fewer patients treated with or without aggressive-approach chemotherapy, were excluded

within 14 days of death among patients who ever received chemotherapy. Five percent of the 453 patients in the lowest quintile received chemotherapy near the end of life, and $12 \%$ of the 614 patients in the highest quintile experienced an aggressive approach to chemotherapy. Compared to standard chemotherapy, use of chemotherapy within 14 days of death tended to be associated with worse survival at 1 year $(-53.5$ percentage points; $95 \% \mathrm{CI}-124.1,17.2 \%$; $\mathrm{P}=0.14$ ) or at 2 years $(-35.1$ percentage points; $95 \% \mathrm{CI}-76.9,6.6 \%$; $\mathrm{P}=$ 
0.10). Because of the relatively small samples of patients receiving chemotherapy near the end of life in geographic quintiles for IV estimates, however, these differences were not statistically significant.

\section{Discussion}

This study explored the clinical effects of chemotherapy continued close to the time of death in a large representative cohort of elderly patients with advanced non-small cell lung cancer in multiple regions of the United States. About one tenth $(8.5 \%)$ of patients who had ever received chemotherapy were still receiving chemotherapy within 14 days of death; this population experienced no survival benefit as determined by three different statistical approaches. These patients were also much less likely to receive hospice care or and more likely to receive it for three or fewer days. These results suggest that patients receiving chemotherapy within 14 days of death do not benefit from this aggressive approach to treatment, and they may also be deprived of good palliative care provided by hospice.

Results from the IVA confirmed that geographic variations exist in use of chemotherapy, but not in clinical outcomes. This suggests that physician practice styles or patient preferences, rather than associated clinical outcomes, may be driving aggressive treatment decisions near the end of life.

Several limitations should be noted. The SEER-Medicare database is restricted to patients aged 65 or older and patients insured by an HMO were excluded in this study, so it is difficult to extrapolate these results to younger patients and those enrolled in managed care. However, $60 \%$ of cancers occur in patients who are 65 years or older, [34] so Medicare covers most cancer patients in the United States [35]. As the data were not collected specifically for research, there may be inaccuracies in some of the variables analyzed, such as the Charlson comorbidity index, but chemotherapy is a costly service with strong financial incentives for accurate billing to Medicare [36,37]. Our data are from patients who died over a decade ago and so treatment options and availability have changed. For example, the modern targeted therapy including an introduction of epidermal growth factor receptor (EGFR) inhibitors [38,39] may have changed the risk/benefit equation. Still, with respect to cytotoxic chemotherapy, our data did not detect any benefit to continuing chemotherapy to near death. Retrospective analyses of patient cohorts defined by death have been criticized because patients' prognosis may often not be apparent to treating clinicians and some deaths may occur despite appropriate efforts to prolong survival [40]. These concerns are mitigated by studying patients who are known to be terminally ill and who die of their terminal illness,[41-43] as we did by focusing on patients initially diagnosed with metastatic non-small cell lung cancer who died of their cancer. A systematic review showed that physicians' survival predictions in terminally ill cancer patients can be inaccurate and generally they are overoptimistic [44]. Palliation is the only goal of therapy for patients with metastatic diseases. In such a case, cure is not an option. If physicians repeatedly give patients chemotherapy very near death because they simply do not see death approaching, they may not be delivering the best care. Similarly, those with a high proportion of unexplained toxic deaths resulted from continuing chemotherapy close to death may be delivering poor care. There may also be a limitation of determining intent of chemotherapy retrospectively: chemotherapy that happens to continue to within 14 days of death may not have been given with the intent of an aggressive approach. However, this is one of the validated measurements that we can use with existing administrative data to assess the intensity of end-of-life cancer care $[11,13]$. Also, despite the fact that survival time is part of both the dependent and explanatory variables, our data showed that the receipt of aggressive-approach chemotherapy was defined independent of patients' life expectancies, which assuages these limitations. Although observational data do not permit clear determination of causality, the consistency of our findings derived from the three sophisticated statistical approaches with a large sample size is compelling.

\section{Conclusions}

We could not detect a benefit in survival from continuing chemotherapy close to death. Furthermore, this treatment was associated with substantially reduced use of palliative hospice care. The Health Services Research Committee of the American Society of Clinical Oncology (ASCO) agreed that treatment could still be recommended, even without an improvement in survival, if it improves the quality of life in the case of metastatic cancer [45]. Our data suggest that an aggressive approach to continuing chemotherapy to very near death likely does not meet this test in that it may result in no survival benefit, and, in fact, in negative outcomes. It is imperative that physicians present honest, individualized, evidence-based information to patients making treatment decisions near the end of life about the expected risks and benefits of chemotherapy.

\section{Acknowledgements}

This research was supported by a grant CA 91753-02 from the National Cancer Institute. The sponsor had no direct influence on the design of the study, analysis of the data, and interpretation of the results, the decision to submit the manuscript for publication, and the writing of the manuscript.

\section{Author details}

${ }^{1}$ Laboratory of Clinical, Epidemiological and Health Services Research, Clinical Research Center, National Hospital Organization Nagoya Medical Center Aichi, Japan. ²Department of Health Care Policy, Harvard Medical School, Boston, MA, USA. 'Division of Population Sciences, Department of Medical 
Oncology, Dana-Farber Cancer Institute, Boston, MA, USA. ${ }^{4}$ Division of General Medicine, Brigham and Women's Hospital, Boston, MA, USA. ${ }^{5}$ Health Services Research Program, Cancer Care Ontario and the Ontario Institute for Cancer Research, Toronto, ON, Canada.

\section{Authors' contributions}

AMS participated in design, conducted the analysis, wrote the manuscript and contributed to the discussion; MBL participated in the design, conducted the analysis, contributed to the discussion and reviewed the manuscript; BAN participated in design, collected research data and reviewed the manuscript; JZA participated in design, contributed to the discussion, and reviewed the manuscript; CCE obtained funding, designed the study, analyzed the data, wrote the manuscript and contributed to the discussion. All authors contributed to data interpretation, made substantive contributions to the manuscript, and had final approval of the article.

\section{Competing interests}

The authors declare that they have no competing interests.

Received: 23 August 2010 Accepted: 21 September 2011 Published: 21 September 2011

\section{References}

1. The PDQ Editorial Advisory Boards: PDQ Cancer Information Summaries: Adult Treatment. National Cancer Institute [http://www.cancer.gov/ cancertopics/pdq/adulttreatment].

2. The Lung Cancer Alliance: Treatment for lung cancer.[http://www. lungcanceralliance.org/facing/treatment.html].

3. The American Cancer Society: Learn About Cancer.[http://www.cancer.org/ docroot/LRN/LRN_0.asp].

4. Matsuyama R, Reddy S, Smith TJ: Why do patients choose chemotherapy near the end of life? A review of the perspective of those facing death from cancer. J Clin Oncol 2006, 24(21):3490-3496.

5. Earle CC, Neville BA, Landrum MB, Ayanian JZ, Block SD, Weeks JC: Trends in the aggressiveness of cancer care near the end of life. J Clin Oncol 2004, 22(2):315-321.

6. Silverman GK, Temel J, Podgurski LM, Paulk ME, Jackson VA, Block SD, Buss MK, Prigerson HG: Do aggressive treatments in the last week of life harm quality of death? Program and abstracts of the American Geriatrics Society 2007 Annual Scientific Meeting Seattle, Washington. Abstract P4; 2007.

7. Temel JS, Greer JA, Muzikansky A, Gallagher ER, Admane S, Jackson VA, Dahlin CM, Blinderman CD, Jacobsen J, Pirl WF, et al: Early palliative care for patients with metastatic non-small-cell lung cancer. $N$ Engl J Med 363(8):733-742.

8. Murillo JR Jr, Koeller J: Chemotherapy given near the end of life by community oncologists for advanced non-small cell lung cancer. Oncologist 2006, 11(10):1095-1099.

9. Emanuel EJ, Young-Xu Y, Levinsky NG, Gazelle G, Saynina O, Ash AS: Chemotherapy use among Medicare beneficiaries at the end of life. Ann Intern Med 2003, 138(8):639-643.

10. Gottlieb S: Chemotherapy may be overused at the end of life. BMJ 2001, 322(7297):1267

11. Earle CC, Park ER, Lai B, Weeks JC, Ayanian JZ, Block S: Identifying potential indicators of the quality of end-of-life cancer care from administrative data. J Clin Oncol 2003, 21(6):1133-1138.

12. Earle CC, Tsai JS, Gelber RD, Weinstein MC, Neumann PJ, Weeks JC: Effectiveness of chemotherapy for advanced lung cancer in the elderly: instrumental variable and propensity analysis. J Clin Oncol 2001, 19(4):1064-1070

13. Earle CC, Neville BA, Landrum MB, Souza JM, Weeks JC, Block SD, Grunfeld E, Ayanian JZ: Evaluating claims-based indicators of the intensity of end-of-life cancer care. Int J Qual Health Care 2005, 17(6):505-509.

14. Zippin C, Lum D, Hankey BF: Completeness of hospital cancer case reporting from the SEER Program of the National Cancer Institute. Cancer 1995, 76(11):2343-2350.

15. The Surveillance Research Program, National Cancer Institute: SEER Registries [http://seer.cancer.gov/registries/data.html]

16. Nattinger AB, McAuliffe TL, Schapira MM: Generalizability of the surveillance, epidemiology, and end results registry population: factors relevant to epidemiologic and health care research. J Clin Epidemiol 1997 50(8):939-945
17. Charlson ME, Pompei $P$, Ales KL, MacKenzie CR: A new method of classifying prognostic comorbidity in longitudinal studies: development and validation. J Chronic Dis 1987, 40(5):373-383.

18. Deyo RA, Cherkin DC, Ciol MA: Adapting a clinical comorbidity index for use with ICD-9-CM administrative databases. J Clin Epidemiol 1992, 45(6):613-619.

19. Klabunde CN, Potosky AL, Legler JM, Warren JL: Development of a comorbidity index using physician claims data. J Clin Epidemiol 2000, 53(12):1258-1267.

20. Bach PB, Guadagnoli E, Schrag D, Schussler N, Warren JL: Patient demographic and socioeconomic characteristics in the SEER-Medicare database applications and limitations. Med Care 2002, 40(8 Suppl):IV19-25.

21. Kaplan EL, Meier P: Nonparametric estimation from incomplete observations. J Am Stat Assoc 1958, 53:457-481.

22. Mantel N: Evaluation of survival data and two new rank order statistics arising in its consideration. Cancer Chemother Rep 1966, 50(3):163-170.

23. Rosenbaum PR, Rubin DB: The central role of the propensity score in observational studies for causal effects. Biometrika 1983, 70(1):41-55.

24. Rosenbaum PR, Rubin DB: Reducing bias in observational studies using subclassification on the propensity score. Journal of American Statistical Association 1984, 79(387):516-524.

25. Bowden RJ, Turkington DA: Instrumental variables. Cambridge University Press: Cambridge, MA; 1984.

26. Landrum MB, Ayanian JZ: Causal effect of ambulatory specialty care on mortality following myocardial infarction: a comparison of propensity score and instrumental variable analyses. Health Serv Outcomes Res Method 2001, 2:221-245.

27. McClellan M, McNeil BJ, Newhouse JP: Does more intensive treatment of acute myocardial infarction in the elderly reduce mortality? Analysis using instrumental variables. JAMA 1994, 272(11):859-866.

28. Newhouse JP, McClellan M: Econometrics in outcomes research: the use of instrumental variables. Annu Rev Public Health 1998, 19:17-34.

29. Stukel TA, Fisher ES, Wennberg DE, Alter DA, Gottlieb DJ, Vermeulen MJ: Analysis of observational studies in the presence of treatment selection bias: effects of invasive cardiac management on AMI survival using propensity score and instrumental variable methods. JAMA 2007, 297(3):278-285.

30. Earle CC, Venditti LN, Neumann PJ, Gelber RD, Weinstein MC, Potosky AL, Weeks JC: Who gets chemotherapy for metastatic lung cancer? Chest 2000, 117(5):1239-1246.

31. Wennberg JE, Fisher ES, Stukel TA, Skinner JS, Sharp SM, Bronner KK: Use of hospitals, physician visits, and hospice care during last six months of life among cohorts loyal to highly respected hospitals in the United States. BMJ 2004, 328(7440):607.

32. Makuc DM, Haglund B, Ingram DD, Kleinman JC, Feldman JJ: Health service areas for the United States. Vital Health Stat 2 1991, 112:1-102.

33. Harris KM, Remler DK: Who is the marginal patient? Understanding instrumental variables estimates of treatment effects. Health Serv Res 1998, 33(5 Pt 1):1337-1360.

34. Yancik R: Epidemiology of cancer in the elderly. Current status and projections for the future. Rays 1997, 22(1 Suppl):3-9.

35. Kenneth ET, Howard D: Health Insurance And Spending Among Cancer Patients. Health Aff 2003, W3.189-W183.198.

36. Riley GF, Potosky AL, Klabunde CN, Warren JL, Ballard-Barbash R: Stage at diagnosis and treatment patterns among older women with breast cancer: an HMO and fee-for-service comparison. JAMA 1999, 281(8):720-726.

37. Whittle J, Steinberg EP, Anderson GF, Herbert R: Accuracy of Medicare claims data for estimation of cancer incidence and resection rates among elderly Americans. Med Care 1991, 29(12):1226-1236.

38. Inoue A, Kobayashi K, Usui K, Maemondo M, Okinaga S, Mikami I, Ando M, Yamazaki K, Saijo Y, Gemma A, et al: First-line gefitinib for patients with advanced non-small-cell lung cancer harboring epidermal growth factor receptor mutations without indication for chemotherapy. J Clin Oncol 2009, 27(9):1394-1400.

39. Langer CJ: The "lazarus response" in treatment-naive, poor performance status patients with non-small-cell lung cancer and epidermal growth factor receptor mutation. J Clin Oncol 2009, 27(9):1350-1354.

40. Bach PB, Schrag D, Begg CB: Resurrecting treatment histories of dead patients: a study design that should be laid to rest. JAMA 2004, 292(22):2765-2770 
41. Earle CC, Ayanian JZ: Looking back from death: the value of retrospective studies of end-of-life care. J Clin Oncol 2006, 24(6):838-840.

42. Gagnon B, Mayo NE, Laurin C, Hanley JA, McDonald N: Identification in administrative databases of women dying of breast cancer. J Clin Oncol 2006, 24(6):856-862

43. Grunfeld E, Lethbridge L, Dewar R, Lawson B, Paszat LF, Johnston G, Burge F, Mclntyre P, Earle CC: Towards using administrative databases to measure population-based indicators of quality of end-of-life care: testing the methodology. Palliat Med 2006, 20(8):769-777.

44. Glare P, Virik K, Jones M, Hudson M, Eychmuller S, Simes J, Christakis N: A systematic review of physicians' survival predictions in terminally ill cancer patients. BMJ 2003, 327(7408):195.

45. American Society of Clinical Oncology: Outcomes of cancer treatment for technology assessment and cancer treatment guidelines. J Clin Oncol 1996, 14(2):671-679.

\section{Pre-publication history}

The pre-publication history for this paper can be accessed here: http://www.biomedcentral.com/1472-684X/10/14/prepub

\section{Submit your next manuscript to BioMed Central} and take full advantage of:

- Convenient online submission

- Thorough peer review

- No space constraints or color figure charges

- Immediate publication on acceptance

- Inclusion in PubMed, CAS, Scopus and Google Scholar

- Research which is freely available for redistribution

Submit your manuscript at www.biomedcentral.com/submit 